\title{
資料
}

インド, セイロン, 東パキスタンの茶業視察報告 *

農林省茶業試駼場 塘 二 郎

\section{Inspection Report on Tea Plantation in \\ India, Ceylon and East Pakistan}

By Nirô ToMo

\section{1 はじめに}

今後目本茶の進展をはかるには，緑茶とともに紅茶の 翰出の振與がその根幹となる。現在茶業は大きな転換期 にあたっている。これに対処すべく育種・栽培・製造の 各分野にわたって研笕が進められているが，この中核で ある品種改良をさらに促進し，乙れによって茶業経営の 合理化の基礎を作ることはきわめて重要なととである。 1964年11月19日加ら12月15日までの27日間にわたり，紅 茶の主産国であるインド，女イロン，東バキスタンを訪 問し，育種を主とし，栽培に関する諾調查空行なった。 おもに調查したのは試験場およびェステートである。ご の調查にあたっては在外公館を始め，現地の多くの方々 の手厚い援助究得ることができた。しかし時間, 言語の 制約があり，当初の目的を十分に果乙得なかったが，そ の概要星報告主る。

この調査実施にあたっては，周到な企画や配虑を賜わ った農林水産技術会議事務局調査課の広野課長，本多課 長補佐，好本事務官，園芸局特産課の河原課長，荒井班 長, 山田技官, 茶業試駼場の加藤場長, 讀井, 鳥井, 小 栗各部長，枕崎支場の上野支場長始め本支場の諸氏に， またセイロンの調查に配虑賜水った椋木瑳睰太，伊達武 夫の両氏にも合わせて㧍礼申し上げる。

\section{2 調 查 日 程 \\ （時刻はいずれる珙地時間）}

1964年11月19日（木） 19.00 羽田発。

11月20日（金）4.30 New Dehli 着。日本大使館三 木韋記官出迎え, 10.00 日本大使館訪問, 大使(留守), 種谷公使，熱田理事官，三宅副理事官にあいさつ，三木 書記官とインドにおける調查計画打合せ。15.00 種谷公 使の招待。Hotel Ambassador 泊。
11月21日（土）日本大使館にあいざ，12.30 New Dehli 発; 13.30 Madras 着, 三井物産株式会社の浅香 氏出迎元，三井物産株式会社訪問，夜浅香氏の招待夕 食, Hotel Connemara 泊。

11月22日（日） 16.00 Madras 発。18.30 Coimbatore 着, K. DEVADAS 氏出迎元，夜同氏招待夕食，Hotel Woodland 泊。

11月23日（月）午前に，K. DEVADAS 氏のあっせえに より K. N. ANATHARIVON 氏訪問。Coonoor にある United Planters Association of South Inida D会長 S. V. NARAYANAN 氏への紹介状を受ける。午後Sugar Cane Institute 訪問（場長 Dr. J. HULJARAM RAO) 展示室で育種事情聴取, 場内外視察。Hotel Woodland 泊。

11月24日（火） 8.00 自動車にて出発，11.00 Coonoor $\odot$ Hotel Reiz 着。' United Planters Association of South India 訪問。S. V. NARAYANAN 氏加ら Singra Estate, Brook Land Estate および Upasi Tea Experiment Station の場長 Dr. C. S. Venhata, RaM. 氏 への紹介状を受ける。午後 Singra Estate, Brook Land Estate 抢よび周辺の茶園視察 Hotel Reiz 泊。

11月25日（水） 8.30 自動車にて出発。 11.20 Devarshora の Upasi Tea Experiment Station 訪問。Dr. C. S. VenKatA. RAM, 氏加ら場の事情聴取，ほ場視 察。同氏の招待を受ける。Devarshora Estate 訪問, Coonoor 経由 19.40 Coimbatore 着。Hotel Woodland 泊。

11月26日（木） K. DEvadAS 氏にあいさつ，11，30 Coimbatore 発, 13.40 Madras 着. Hotel Connemara 泊。

11月27日（金）17.05 Madras 発, 19.50 Colomba 着。日本大使館副島書記官, P.P. PIYASENA JINADASA

* 茶業技術研究 No. 30, 91 104 (1965) より転載 
夫妻出迎之，高瀬大使の招待夕食。Hotel Nippon 泊。

11月28日（土）JINADASA 氏の車で同氏の事務所訪問 後日本大使館にあいさつ，高瀬大使からセイロンにおけ る一般茶業事情聴取，三木書記官と調查計画その他につ いて打合せ。午後日本人運動会に出席。Hotel Nippon 泊。

\section{1月29日（日）市内見学。}

11月30日（月）9.00日本大使館の自動車でJINADASA 氏と同行, Kandy の Division of Batany Department of Agriculture の村上利男，吱本敏雨技官訪問，午後両 氏から研究事情聴取, 周辺茶園視察, 坂本技官宅におい て画氏の招待夕食 Kandy Rest House 泊。

12月 1 日（火）坂本技官の同行を得 $\tau, J I N A D A S A$ 氏 らとともに，自動車にて Rathschild Estate 訪問。また 各所に扔いて茶園視察。午後 Mahavilla Estate および 周辺茶園見学, Talawakele Rest House 泊。

12月 2 日（水）坂本技官，JINADASA 氏らとともに St. Coombs $の$ Tea Research Institute 訪問, 場長 A. W. R. JOACHIM 氏注面接, A. V. RICHARDS 氏方ら 繁殖状沉恥取, 研究注場見学, 午後 R. L. WICHREMAsinghe 氏拉よび B. P. M. PERera 氏からそれぞ れ肥料，病害虫関係の研究事情聴取。Talawakele Rest House 泊。

2月3日（木）Tea Research Institute 再度訪問, A. R. Sebastiampillai 氏から育種事情聴取，育種ほ 場, 製茶工場見学。Nuwara Eliya 地区茶園見学。1 4.00 坂本技管老 Nuwara Eliya の駅に送る。Haputale 地区 茶園見学, Belihul Oya Rest House 泊。

12月 4日 (金) Ratnapura $の$ Tea Research Institute Low Country Station 訪問, 場長 Dr. H. FERNANDO 氏分ら研究事情聴取, 研究活場見学, Hotel Nippon 泊。

12月 5 日（土） 9.00 大使館訪問，高瀬大使汇調㚗結 果報告，また，三木書記官にも結果報告, Hotel Nippon 泊。

12月6日（日） 7.15 Colombo 発, 11.00 Madras 着。17.40 Madras 発, 21.10 Calcutta 着。 Hotel Great Eastern 泊。

12月 7 日（月） 8.45 Calcutta 発, 10.05 Dacca 着。 日本総領事领浅开領事, Agricultural Extention Training Institute の山口, 岩岡西技師出迎充, 日本総領事 館訪問, 竹中総領事に西いさつ, Sylhet 亿持ける調査計 画打合垃, 竹中総領事の招待夕食, Hotel Shabaleag 泊。

12月 8日（火）浅井領事の案内でPakistan Tea Board 訪問, 全長のS. A. E. HUSSAIN 氏から Lakcatoorah Estate $の$ CUTHILL 氏, Pakistan Tea Rerearch Station の K. A. HASAN 場長への紹介状を受活る，午後 Agricultural Extention Training Institute 訪闆, 研
究事情聴取，研究注場見学，山口，岩岡両技師招待の夕 食, Hotel Shabaleag 泊。

12月9日（水） Agricultural Extention Training Institute の山下技師および同氏の助手 A. M. MUTIN 氏とともに 12.40 Dacca 発, 13.40 Sylhet 着, SubDivision Agricutural Office 9 S. UllaH 氏出迎光, Sub-Division Agricultural Office 訪問, Khadim Nagar Fishiries Dah Banglow 泊。

12月10日（木）Banglow にて District Agricultural Officer の A. SIDDIQU 氏と調查計画打合せ，Khadim Tea Estate, Lackatoorah Estate 訪問, 周辺茶園視察, 前日と同じ Banglow 泊。

12月11日（金）山下技師，A. M. MUTIN, A. SiDDQU 氏らとともに Sub-Division Agricultural Office のジ 一プにて Pakistan Tea Research Stationに向かう。途 中 Maibi Bazar飞て水稲試験の收量調查見学, Kalaura 加ら汽車にて 19.30 Srimangal 着, Pakistan Tea Research Station 泊。

12月12日（土）午前 Pakistan Tea Research Station 訪閭，場長 K, A. HASAN 氏沈いさつ，同氏の案内で 各研究室の研究事情聴取, 試験注埸見学, 13.20 Srimangal 発, 17.50 Fenchugani 着, 神戸製網株式会社尿素 工場泊。

12月13日（日）汽車にて 9.00 Sylhet 着, 周逝茶園 視察, 14.00 Sylhet 発, 15.00 Dacca 着。竹中総領事 の招待夕食, Hotel Shabaleag 泊。

12月 4日（月）日本総領事館訪問，竹中総領事－线井 領事侸調查結果報告, 浅井領事の招待昼食, 16.40 Dacca 発, 18.00 Calcutta 着, Hotel Great Eastern 泊。

12月15日（火） 7.00 Calcutta 発，21.20 東京着。

\section{3 インド 南 部}

1964年11月20日 New Dehli に到着してから11月26日 まで滞在した。この間茶産地であるCoononr，Devarshora 訪問し, Upasi Experiment Station, 主要エステ ートにおいて茶業事情の調查を行なった。

日本大使館の種谷公使，三木畫記官の御指導岂いただ き, Coimbatore では K. DEVADAS 氏の御配否をいた だいた。調查したのはるずが2日間であり，十分な調 查はできず，しかもその結奥は断片的なものに終わっ た。

\section{1 調 査 榴 要}

栽培種：インドの南部は Nigiris を中心に茶の栽培が 発展し，種子注古く支那種が流いったが，大部分はせイ ロンから入れたアッサム雑種である。茶園惟ぱくな個 体で構成されているが, 低地はアッサム雑種, 中地注了 ッサム雑種を主体とし一部の支那種, 高地况支那種を中 心とし一部のアッサム種から成立っている。 
品種の育成：現在繁殖には種子がよく利用され，種子 用の苗床も多い。まだ育種事業は大規模に法なるれて いない。䏍種方法注主として分離育種法で, 試験場, 主 要エステートで行なっている。現在まで育成された品種 は SA-6, C-194, 6017, GW-1，SP-1 で, 有望系統 として B/6/63，B/6/62，B/5/63 がある SA-6，C-194 は高地向の品種で饬り, 6017, GW-1, SP- 1 は呧, 中 地向の品種である。

繁殖 :さし木繁殖法は改善され良い成績を打さめてい る。穂木は台刚りした後に発生する生育の打う盛な徒長 枝の夕を使用し，上位の 1 〜 葉ぐらいの未熟な部分と 下部の硬化した部分を除き，さし穂の長さ $5 \mathrm{~cm}$ 程度の 一葉ざしで，藻は大きくても切断することをしない。発

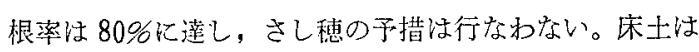
ジャングル土鎄と砂地を同量に配合したるのを使用し， pH 5.5 6.0 亿調整する。Eelworm の被害が大きいの で，必ず鉄板で $65^{\circ} \mathrm{C}$ 爇し駆除する。さし木の時期注 $4 \sim 5$ 月と $8 \sim 9$ 月の 2 回行なわれる。始め直径 $25 \mathrm{~cm}$, 高さ $5 \mathrm{~cm}$ の素烵のは台にさす。

発根狱況は高地と低地で異なり，低地，中地ではさし 不後 7 週間，高地では $8 \sim 10$ 週間を要する。小无にさ してから 3〜4月後約 $10 \mathrm{~cm}$ 程度に生育した時に! 直径 $10 \mathrm{~cm}$, 高さ $30 \mathrm{~cm}$ の底なしい指りエチレン袋に移植す る。さらに $8 \sim 12$ 月後にほ場に定植子る。12月，1月， 2 月，3月が乾燥期であるため，植えいたみがなく，こ

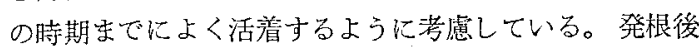
配合肥料（硫酸フンモニウム 35 : 過リン酸石灰 8 : 硫酸 カリウム $15:$ 硫酸マグネシウム 15) $28 \mathrm{~g}$ 水 $8 l$ に溶し たものを1週間に1回の割合で施し，苗が大きくなって からは，この液の倍量の浱度のものを施す。日抢括いの 材料法ヤシの実の䋐維で編えだ網状のもので、日おおい の高さ法大きい苗床で $160 \mathrm{~cm}$, 小さいものでは $60 \mathrm{~cm}$ 程 度である。な妨，大きい苗床で，最初にさした小就ちの さし木苗をさらにどニルで被覆している場合もある。

苗床時に発生する害虫は, aplis, yellow mite, purple mite, scarlet mite, 線虫として root-knot nematodes, などで, 病害住 brown root rot, Pythitum, charcoal stump rot, black rot などである。

定植後の管理：茶園はほとんどが傾斜地で等高線状に 横う称の場合が多い。中地と高地とでは生育に差が市 り，また，立地条件の造いで栽植様式は一様ではない が, $120 \times 60 \mathrm{~cm}$ (う权幅×株間), $120 \times 120 \mathrm{~cm}, 135 \times$ $60 \mathrm{~cm}, 2$ 条植えの $150 \times 75 \times 75 \mathrm{~cm}$ である。仕立法は生 育中庸の園で, 定植 1 年目には樹高 $25 \sim 30 \mathrm{~cm}$ のところ でせえ枝し，2 年目では 40〜 50cm のところでせえ枝し， その後摘採を始める。3 年目には樹高 $60 \mathrm{~cm}, 4$ 年目に は樹高 $80 \mathrm{~cm} ， 5$ 年目には樹高 $100 \mathrm{~m}$ に達する。だいた 、低地, 中地で注摘採後 $4 \sim 5$ 年で, 高地では $6 \sim 7$ 年
で樹高 45〜 60 cm のところで中刚りする。この中刚りに は1 1 エーカー当たり約 4,500 月（男 1 日に 130 株中归り する) 要要方る。除草は年 4〜5回行ない, 1 エーカー 当たり $5,000 〜 6,000$ 円要する。

肥料は収量に応じて施し，製茶量10ポンドに対し䇪素 1 ポンドの割合に，リン酸注年間30ポンドを施すのを基 準としている。すべて配合肥料（窒素180：リン酸45：カ リ90索使用し，年 2 回に分施する。1 回目は半分の窒素 と全リン酸，カリを浅耕しながら施し，2回目に残りの 半分の空素を施す。この作業代男 3 人女 6 人約 1,200 円 を要する。収量の多いエステートでは三要素の配合肥料 定年 3 回爷分施し，毎年1列扮き深耕する。

収量は地域差、エステート差があり，その実態を知る ことは图難であるが，Coonoor では1エーカー当たり約 1,000 ポンド(製茶量)以上をあげており，収量の多い エステートでは 1,600 ポンド以上の収穫がある。摘採は 年中行ない, 高地では8 日間隔に，低地では6日間隔に 摘採し，女1人，1日の責任収穫量は 30 ポンドである (賃金1日1.53ルピー，120円)。収量良好な茶園での中 刈後の収量（製茶量）は，高地では 1 年目500ポンド, 2 年目 700 ポソド， 3 年目 900 ポンド，4年目1,200ポンド， 5 年目 1,500 ポンド，低地では 1 年目 700 ポンド， 2 年目 900 ポンド, 3 年目 1,200 ポンド, 4 年目 1,700 ポンド程度 である。

被陰樹はセイロンよりも密汇植えられている。樹種は いろいるあるが括もなもは, crotalaria, acacia, grevillea, albizzia, erythrina, gliricidia, eucalyptus どで, とくにこの地方の特産である eucalyptus の多い のが目立っている。

病虫害: 葉枝の括もな病害性 blister blight, blach rot, brown blight, grey blight, copper blight, branch canker, red rust, hypoxlon, poria, leplothrium など で, 根の打もな病害は, red root rot, brown root rot, violet root rot, charcoal stump ;rot, root splitting disease, formes lignosus, などである。

容虫のおもなものは, scarlet mite, purple mite, yellow mite, red spider, scale, shot hole borer, leaf miner, thrips, aphis, tea tortrix, nettle grubs, cockchafer grub, fuggot worm, green fly, mealy bugs, 線虫として， root. knot nematodes などである。

Upasi Tea Experiment Station (標高 1;200m) は䔕 培, 土境, 病害の研究を行なっている。抢もな研究は土 袞調査, 栄㝨系の特性榆定試験, 繁殖に関する研觉, 仕 立法に関する研究などである。特性検定試験注12〜3月 の乾燥期に対する耐干性と， 6〜10月によく発生する blister blight に対与る抵抗性について検討している。 
表 1 麗気象表 (Upasi Tea Experiment Station)

月 別最高気温最低気温湿㽝度 降雨量 降雨日数

\begin{tabular}{|c|c|c|c|c|c|}
\hline 1 & $26.1^{\circ} \mathrm{C}$ & ${ }_{14.5^{\mathrm{C}}}$ & $90.2^{\%}$ & $\underset{7.9}{\mathrm{~mm}}$ & 0.3 \\
\hline 2 & 28.0 & 15.9 & 85.1 & 16.6 & 2.0 \\
\hline 3 & 30.1 & 17.1 & 83.0 & 18.6 & 1.7 \\
\hline 4 & 29.1 & 18.3 & 88.6 & 71.2 & 10.0 \\
\hline 5 & 26.8 & 18.6 & 90.7 & 265.7 & 18.3 \\
\hline 6 & 23.4 & 18.0 & 90.4 & 270.7 & 23.0 \\
\hline 7 & 22.8 & 17.6 & 97.5 & 732.2 & 28.0 \\
\hline 8 & 23.3 & 17.8 & 95.0 & 332.2 & 27.3 \\
\hline 9 & 24.2 & 17.4 & 94.9 & 205.7 & 21.7 \\
\hline 10 & 25.1 & 16.9 & 91.8 & 236.1 & 17.0 \\
\hline 11 & 24.4 & 17.0 & 90.5 & 24.7 & 7.3 \\
\hline 12 & 24.6 & 15.1 & 91.9 & 31.0 & 3.3 \\
\hline $\begin{array}{l}\text { 計 } \\
\text { 平 均 }\end{array}$ & 25.6 & 17.0 & 90.8 & 2212.6 & 159.9 \\
\hline
\end{tabular}

注 : 1961 1963年の 3 力年平均

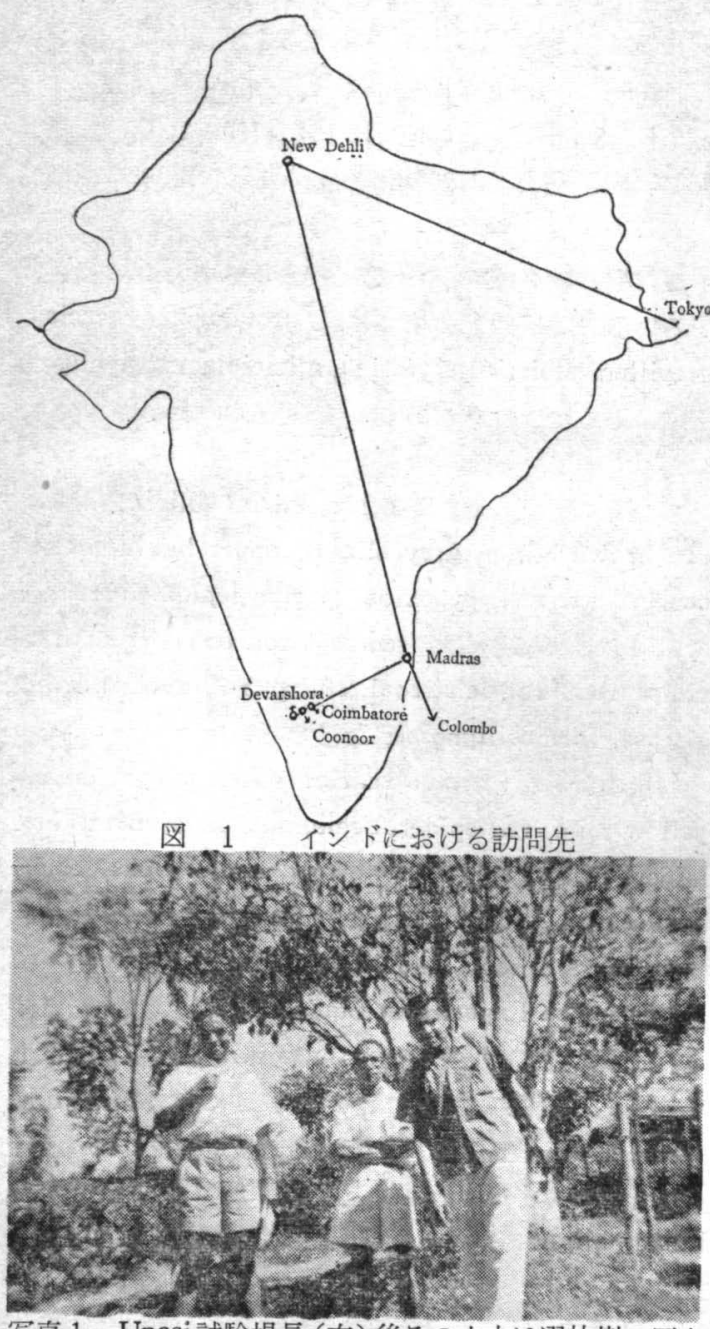

写真 1 Upasi 圾験場長(右) 後乃の立木は選抜樹の原木

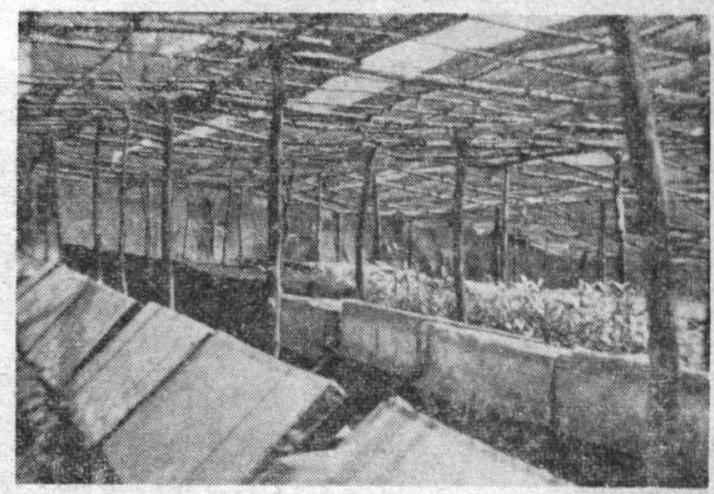

写真 2 さし木苗床 (Brook Land Estate)

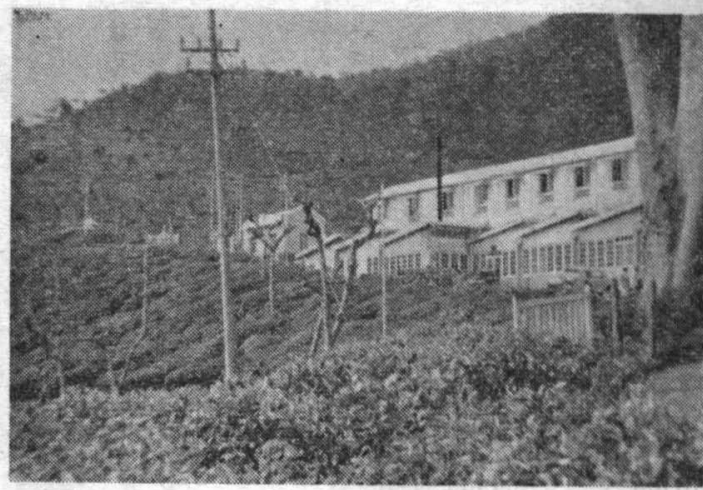

写真 3 Singra Estate

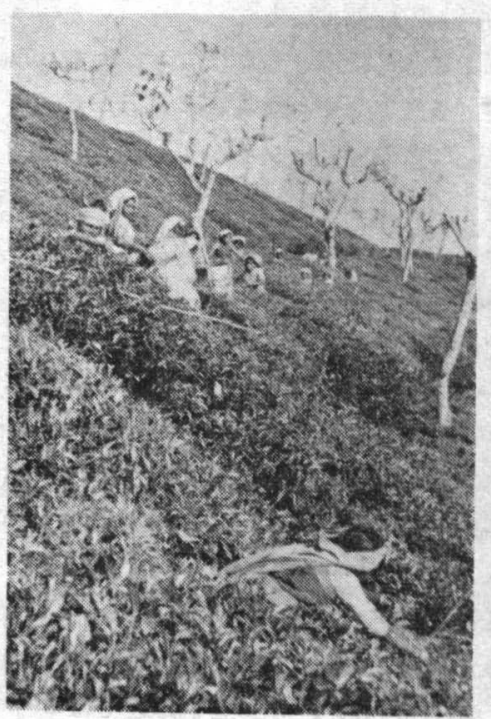

写真 4 茶 摘 夕

$$
4 \text { セイロン }
$$

11月27日に Madras 省出発し, Colombo に到着しこ から 12 月 5 日まで滞在した。その間に Kandy, Talawakele, Nuwara Eliya, Haputale, Ratnapura を訪問 L, Tea Research Institute, Tea Research Institute Low Country Station および主要エステートにおいて 


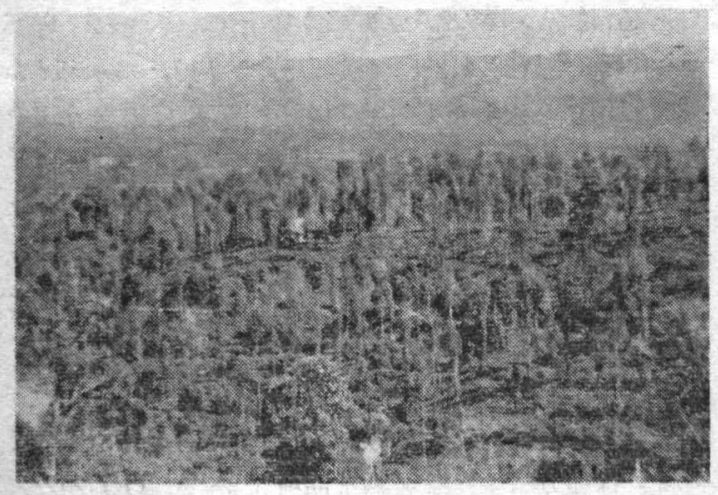

写真 5 Devarshora 附近の茶園

情の調査を行なった。

日本大使館の高瀬大使，副島書記官の御指導をいただ き,また Division of Botany Department of Agriculture の坂本, 村上の両技官, 伊達鉄工所代理店の P.P. JINADASA 氏兄弟の好意的な協力を得た。調査にあたっ ては，坂本技官の協力を得たが，その都度日本における 茶業技術の説明を求められたこともあり，十分な時間は なく調査はほ場関係のみに終わりしかもその調查は断 片的なものとなった。

\section{1 調 查 概 要}

栽培種 : 大別すると，高地は支那種を主体とし一部の アッサム雑種, 中地はアッサム雑種を主体とし一部の支 那種, 低地はアッサム雑種から構成されている。

(1) 品種の育成

育種事業が行なわれたのは1938年以降で, 既成茶園お よび自然種子からの選抜による分離育種法が主として取 り入れられ，交雑育種法が行なわれるようになったのは 2 年前からである。

分離育種法：1938 年以降の試験場で育成された系統 は, 試験場と 3 エステートで選抜されてきた。1958 年以 降育種事業拡充のため 4 試験地が設立され，選抜は主と して Ratnapura の Low Country Station で行なうよ うになった。一方，エステート（主として高地のェステ 表 2 品種の普及状況

\begin{tabular}{|c|c|c|c|c|c|c|}
\hline 品 & \multicolumn{2}{|c|}{ 種 } & 栽 & 培 & 面 & 積 \\
\hline TRI & 2023 & & & & 8.75 & エーカー \\
\hline " & 2024 & & & 113 & 3.75 & \\
\hline " & 2025 & . & & & 3.75 & \\
\hline " & 2026 & & & & 1.50 & \\
\hline " & 2027 & & & & 3.75 & \\
\hline " & 22 & & & & 1.75 & \\
\hline " & 777 & & & & 7.50 & \\
\hline & その他 & & & & 9.25 & \\
\hline & 計 & & & 359 & 0.00 & \\
\hline
\end{tabular}

ート）でも独自の立場から育種を進め，多くの品種が育 成されている。試験場で育成されたおもな品種の普及状 況を表 2 に示す。

その他エステートで育成されたおもな品種は, MT 18, DG 39, CG 4, CH 3, DT 1, DT 95, KN 16/1, KI 136 , KI 45 , KI 150, N 3, NL 3/1, NL 4/2, CY 9, NY, CH $9 / 3$ などである。

交雑育種法：交雑育種法が取り入れられたのは 2 年前 で，高地，中地，低地に適する品種の育成を行なってい る。おもな育種目標は多収，耐病虫性で品質も目標では あるが，品質の差は高地と低地とでは明らかであり，低 地でどのようにしてる高地ほどの品質を求めることは困 難であり，品質は標高によって解決すべきものとし，品 種の育成による品質改良の目標は, 同一地帯内での比較 においてである。

茶樹は一年中不規則に開花するが，開花の多い時期は 4月で，交配は主としてての時期に行なうが，また，適 宜に行なっている。この方法による育種事業はまだ組織 的に行なわれておらず，交配組合せ数む少なく，1組合 せの交配花数も 100 花程度である。採種は交配後 $10 \sim 11$ 月で，結果率は組合せによる差異はあるが，交配時期に よる差異は少なく, 平均 20〜25\%程度である。採種後た だちに 1 日間浸水し，1日間干ぼしし，種皮にき裂を生 ぜしめてから，準備した直径 $10 \mathrm{~cm}$ ，高さ $30 \mathrm{~cm}$ の底なし のポリエチレン袋（土塨はグナテマラ土塞）には種す る。は種後 $3 \sim 4$ 週間で発芽する。定植の時期は降雨で 決定されるが，だいたいは種後12〜13カ月である。個体 はうね幅 $120 \mathrm{~cm}$ ，株間 $120 \mathrm{~cm}$ に植える。

個体選抜 : 定植後 1 年間は均整栽培で, 選抜は 2 年目 から行ない, 次のようなものは淘汰する。(1) 摘採面のあ らいもの。(2) 芽数の少ないもの。(3) 超直立型で生育速 度のおそいもの。(4) 摘採後の生育の徳いもの。(5) 成葉 の小さいもの。(6) 摘芽の小さいもの。(7) 摘節間の短か いもの。(8) 開花数の多いもの。(9) 収量の少ないるの。

収量調查には, 最初の 2 回の摘採を除き， 3 回目から の連続 8 回の収量の多少によって, 供試個体の約半分程 度を選抜し，次の連続 8 回の収量によって, 第 1 回目に 選抜した個体数の半分程度を選抜する。このように連続 8 回の収量をひとくくりとして選抜を繰り返す方法をと っている。この方法は次の表 3 の成績に基づき早期に検 定できるようにしたものである。品質の良否は肉ひき機 を使用しての少量製茶, chloroform test によって判定 する。このようにして選抜した個体は，その後摘採せず 放任し苗を取りさし木して，発根状況を調查して特性検 定試験に供試する。

特性検定試験におけるおもな特性は, blister blightに 対する抵抗性, meadow, root knot に対する抵抗性, mite, shot hole-borer, scale に対する抵抗性, 耐干性 
などで，試駼期間は 4 カ年間である。これによって選抜 された系統を繁殖し，試験地あるいは土ステートにおい て大規模に比較試験を行なう。

表 3 収量 の 相 関

\begin{tabular}{c|c|c|c|c}
\hline 摘採日数 & 120 回 & 80 回 & 48 回 & 42 回 \\
\hline 1 & +0.335 & +0.405 & +0.396 & +0.473 \\
2 & +0.728 & +0.783 & +0.746 & +0.370 \\
3 & +0.658 & +0.734 & +0.816 & +0.688 \\
4 & +0.674 & +0.745 & +0.898 & +0.796 \\
5 & +0.859 & +0.723 & +0.930 & +0.824 \\
6 & +0.891 & +0.961 & +0.929 & +0.858 \\
7 & +0.867 & +0.880 & +1.926 & +0.834 \\
8 & +0.889 & +0.973 & +0860 & +0.802 \\
9 & +0.866 & +0.958 & +0771 & - \\
10 & +0.867 & +0.954 & +0.952 & - \\
\hline
\end{tabular}

さし木繁殖技術吕暜及し，育成品種はよく増殖され， これらは従来の突生園の 2 倍の収量があがっているとの ことである。

(2) 栄羵系の繁殖

苗床：床桠 $30 \mathrm{~cm}$ の短ざく状で，ていねいに行なう 埸合法，床の予定地を $15 \mathrm{~cm}$ 程度耕起し，底に $5 \sim 7 \mathrm{~cm}$ 砂利をひいて排水をよくする。床の高さ洁 $15 \mathrm{~cm}$ 程度と する。

穂木：台刚りした後に発生する生省の抢う盛な徤辰枝 のみ悡木とし，上位の1〜4葉の末熟な部分と下部の 硬化した部分を除いた部位のみを使用し，さし筹の長さ $5 \mathrm{~cm}$ 程度の一葉, 斜好ざしする。発根率は良く $90 \%$

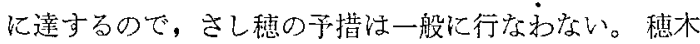
の予措として，穂木党切り取る 2 週間前に上部の $1 \sim 2$ 菜觉摘除し，芽の発育を適度炕促進する場合るある。

さし木床：小壮ちにさし，発根後直径 $10 \mathrm{~cm}$, 高さ 30 $\mathrm{cm}$ の底なしのポりエチレン袋に移植する場合も㐫るが， 多くはポリエチレン袋に直接にさす。床土はグァテマラ を 3〜6年間植えた土定利用する場合が多い。これ㳊分

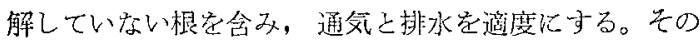
他ジャングル上壤, 泥炭, 砂土定適度に配合して床上と

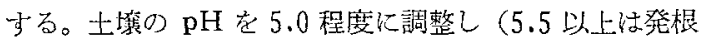
がきわめて䭴い), nematodes 駆除する。

日おおいの忉料注インドと同じで，ヤシの実の緎維で 編んだ網状のもので，網の目は $0.5 〜 1.0 \mathrm{~cm} ，$ 照度は40〜 $50 \%$ とし，日掠いの高さは大きい苗床では $160 \mathrm{~cm}$ ，小 さいものでは $60 \mathrm{~cm}$ 程度である。

さし木の時期は $8 \sim 10$ 月で，さし木後低地では $6 〜 7$ 週, 高地では $7 \sim 8$ 週に発根し，施甩は $8 \sim 12$ 週後必要 で, 2 週間に 1 回の割合で, starter mixture (窒素13.9， リン酸 17.5 ，カリ 12.0 )を水 $45 \mathrm{l}$ に $110 \mathrm{~g}$ とかしたもの を6〜8回施し，その後有機質の sterameal mixture
（窒素6.4，リン酸9.2，カリ9.4）を施す。そのほか T/75 mixture（窒素20.6，リン酸14.75，カリ12.5）を45lの 水に $110 \mathrm{~g}$ とかしたものを発根後 2 週間間隔に施す場合 もある。

苗床時に発生の多い寞虫は, aphid, scale insect, yellow mite, purple mite, scarlet mite, red spider, white grub, cut worms などであり，5〜 7 週間間隔に 駆除する。

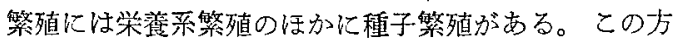
法は自然交雑種子の利用ではなく，隔離採種したもので ある。採種方法仙試験場 育成品種である TRI 2023, TRI 2024, TRI 2026 の3品種堂使用し，そのう方の 2 品種㟟選えで適宜に配置して栽培する。たとえば TRI 2023 と TRI 2024 の交互植付け，TRI 2023 と TRI 2026 の5対 1 の割合の植付けなどで亦る。これらの種子穵利 用した場合，均整度は高く，両親とかわらない良い生育 を示す。

定植後の管理：さし木後 8～11月でほ場に定植する。 標高の高いところ，条件が悪くて生育の悪いところでは 育苗期間を長くし，必ず健全な良い苗の久学使用する。 苗木が早く良い樹型をつくるように苗木時に上部を摘除 する場合るある。定植時の栽植様式法いるいるあり 120 $\times 60 \mathrm{~cm}$ (う称幅×株間)，120×75cm, $120 \times 90 \mathrm{~cm}, 120$ $\times 120 \mathrm{~cm}, 120 \times 150 \mathrm{~cm}, 150 \times 90 \mathrm{~cm}, 150 \times 150 \mathrm{~cm}, 150$ $\times 180 \mathrm{~cm}, 2$ 条植えの $120 \times 30 \times 90 \mathrm{~cm}, 150 \times 75 \times 75 \mathrm{~cm}$ が扮をなのであるが，うね福120〜150cm，株間60７5 $\mathrm{cm}$ だいたい 1 エーカー当たり 5,000 本程度が適当であ る。

アッサム雑種は直立型で，早く樹型定良くするため， 苗椺時にせ九枝する場合，定植時にせえ枝方る場合もあ るが，主翰を安げて側枝の発生を促寸方法も講じてい る。一般に定植 4 力月後に $30 \mathrm{~cm}$ 程度のところでせえ枝 し，その後6力月ごとに前のせ九枝面から $5 \mathrm{~cm}$ 程度上 のところでのせん枝を繰り返し，樹高 $45 \mathrm{~cm}$ に達する定 植 2 年目から摘採安開始する。定植 1 年目には, 配合肥 料 T200（窒素20.6：リン酸 $13.75 ：$ カ15.0）是 1 株当 たり $90 \mathrm{~g}$ を〜 6回に分施し，2 年目には $120 \mathrm{~g}$ を〜 6 回に， 3 年目には $180 \mathrm{~g}$ 䘮 $2 \sim 4$ 回に分施する。

生育中唐な地带では， 3 年目に樹高 $60 \mathrm{~cm} ， 4$ 年目に $80 \mathrm{~cm}, 5$ 年目に $100 \mathrm{~cm}$ 程度㑢するが，この程度に達 すると高さ 45 60 cm のところで中刚りを行なう。生育 は高地ではおてく，低地の環境の良いところで法早いた めに, 中刈りの周期は高地では $5 \sim 6$ 年, 低地では $3 〜$ 4 年である。この中刚りは生長のやや不活発な11〜 3月 までの間に行なう。この中刈りの目的は，(1)摘採定繰り 返すごとに樹高怯高くなり，容易に摘採できず，経済的 にも不利で西る。(2)株に一定の休䓹を与克ることにより 樹勢を良くする。(3) 良い型に発育する枝の発生を促進し 
樹型を良くし，良い摘採面を作る。(4)摘採徯の生育が良 い。(5) 良質の摘芽が得られる。

\section{(3) 施肥}

収量と最子関係の媣いものは空素で，リン酸の効果は みられない。收量と咥素量との関係は+0.987, リン酸 量との関係は+0.070, カリ量との関係は+0.697であ

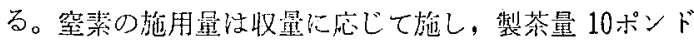

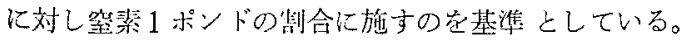
現在成机対与る施肥量洼4のとおりである。

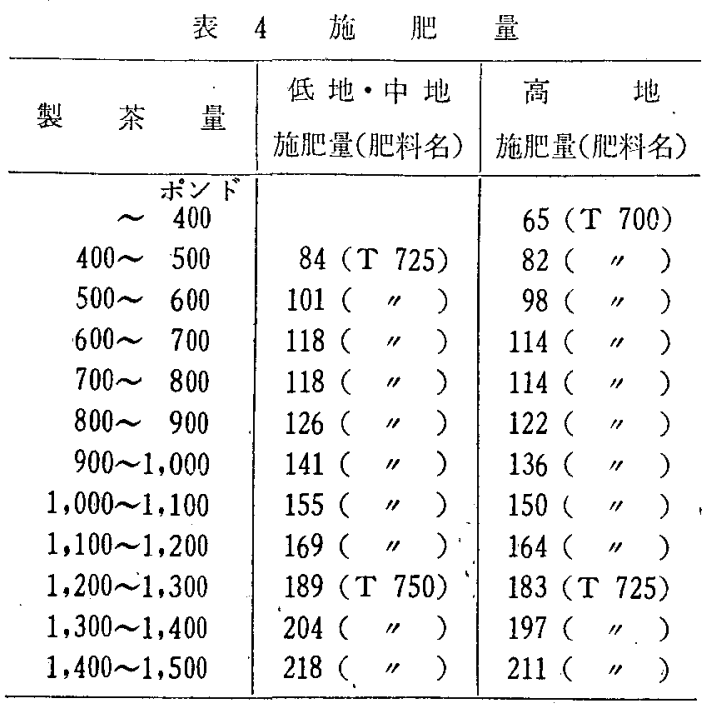

注：単位は 1 エーカー当たりボンド

T $725 \quad \mathrm{~N} 103: \mathrm{P}_{2} \mathrm{O}_{5} 27.5: \mathrm{K}_{2} \mathrm{O} 60$

T $725 \quad \mathrm{~N} 103: \mathrm{P}_{2} \mathrm{O}_{5} 27.5: \mathrm{K}_{2} \mathrm{O} 75$

T $750 \quad$ N. $103: \mathrm{P}_{2} \mathrm{O}_{5} 27.5: \mathrm{K}_{2} \mathrm{O} 90$

低地で品種を供試しての結果であるが，施肥量の詿験 で1エーカー当たり製品で5450ポンドの收量をあげ， 1 エーカー当たり窒素の!施用量は 500 ポンド施す必要があ る。また，2年間にわたる施肥回数の試験で，.2力月ご とに11回分施した区が最す多取で，回数の少ない区ほど 収量が少ないなどの結果がある。しかし，現在合理的な 施肥法はまだ明らかでなく，成分の割合は䇪素2：リン 酸 1 ：カリ 1.5 と考えられている。

アッサム雑種は窒素が欠乏すると, 苗木でも成木でも 成菜が桃色に変色する。硫安などを施すと回復するが， また，㽷素の葉面散布でも回復する。しかし，㽷素の施 用は茶樹の生育㧍よび茶の品質を悪くし, 窒素肥料梳 安が主体である。現在䟽安の連続施用の悪影響は現われ ていない。

収量を多くするための各種肥料試験が行なるれ，窒素 質肥料の多用効果が明らかになってきたが，現在窒素犋 施用量と茶の品質との関係が問題となってきている。こ の関係は高地, 中地, 低地では栽培種も違って和り, 窒 素施用量に対する増収効果の程度る異なっていて，まだ
明らふではない。試験場の年収量（製茶量）1400ポンド のほ場での試験では，窒素 240 ポンドの多量施肥は茶の 品質低下の傾向が烈められている。

滈地と低地との茶の品貿の違いについて検討されてい る。摘採芽の成分について，高地産のものと低地産のも のと比較すると，高地産のもののほうが含有量の多いの はアルミニウムのみで，逆に低地産のものの注うが含有 量の多いの注窒素，リン酸，カリ，マンガン，マグネシ ウム、ナトリウムで，カルシウムは差がない。現在アッ サム雑種を供試し，他の成分を同一にして，アルミニウ ムの影縓について試験中であり，今のところてルミシウ

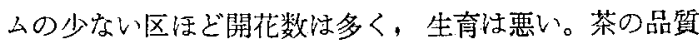
はまだみるでに至っていない。との研究はアルミニウ ムが茶の品質に影響与るのではないかと考えて行なった ものである。高地は支那種が栽培されているが，支那種 のほうがアッサム雑種よりも標高が高くなるほど品質が よくなる傾向が強く，なぜ蓠地のほうが品翼がよいがは 明らかでない。

その他問題となっている歹のは，(1) マグネシウム久 之。(2) 严鉛久そ（まだ茶の品質への影響は不明)。(3) 栄 養系で改植した場合に，ごく初期に発生する窒素久灭。 (4) 低地に発生する栄䆣系の枯死(これは多くの場合に根 のデンブン眝蔵量が少ないので，排水をよくすること，

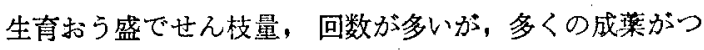
いている時期のせえ枝，必要以上の执枝它避けるよう， に注意している）等である。

(4) 被陰 樹

現在植えられているおもな樹種は次のものである。 albizzia (Falcata, Stipulate), grevillea, aleuritis, stylosanthus, tephrosia, acacia, erythrina, gliricida.

被陰樹の効果について法各所で研究され，被陰樹の刚 落としや落葉によって畑に還元される成分について，被 陰樹の有無と茶の生育収量, 茶の品質との関係, 茶樹へ の肥料効果などが検討されているが，その結果はまらま らである。

効果を認める報告は，(1) フッサム雑種では生育が良く なる。(2) 被除樹の刚落としや葉の落下により有機質の逞 元が多い。(3)茶樹との根の分布が異なり，茶樹で沙收 し得ない下層土から養分を吸収し，刚落とし，落葉で還 元する。この際微量要菜の供給も大きい。(1) 硫安施肥の 場合その窒素効果が大きい。(5) マ入科の被陰樹の場合, その周辺の茶樹はよく固定窒素を利用する。しかし，多 肥栽培の時にはその利用は減退する。(6) cover grass が なく，土地の肥よく度が低い時に被除樹は必要である が，土地の肥よく度は維持しない。(7)台灲り，中刚り の場合にはその後の生育を良くする。とくに乾燥期に向 かって行なう場合にはその効果は大きい。(8) 被㓌樹のな 
い場合には，同じ収量をあげるには多くの肥料を必要と する。

効果を認めない䇉告には (1) 土塨水分の競合をともな う。(2)幼木への被陰はよくない。(3) 被陰澍のない時に 施肥の効果があがる。(4) cover grass の効果注被㓌樹の ない時に大きい。(5)病害虫の発生を多くし，感染する。 (6) 上壇型の違いでその効果は一様でない。

試験場では，被除樹として grevillia 它供試し，9年 閶にわたる被陰樹と施肥量と它組み合せた試験で忹，茶 樹の生育, 収量, 施肥量への被陰樹の効果は認められて いない。茶の品質人は水色にやや良い傾向核認められる が，夲の效果は少なく，製品の価格差はない。以上のよ
うにその効果はまちまちで, 今後どの程度の日㓌を生ず るような栽植㥞式が良いの汃，とくにマメ科の被除樹に ついて检討の必要があるうが，今のところ次のように推 定している。高地は傾斜地が多く，低地に比較して生育 にはより多くの土㗧水分が必要で，このためにはむしる

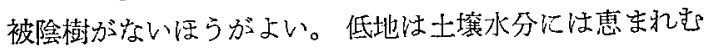
しろ日照要必要とする。したがって乾燥期のみに被㓌樹 の必要があり，その他の時期にはないほうがよい。一方 ほ場における労働関係からみると被除樹は好ましい。

(5) 病害 おもな病害は次のものである。

葉 : oil spot disease, blister blight, black blight, rim

表 5 茶園面積・生産量・輸出量 (1955年以降)

\begin{tabular}{|c|c|c|c|c|c|c|c|}
\hline 年 度 & 茶園面積 & 茶生産量 & 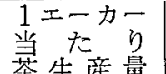 & 輸 出 量 & 輸出金額 & \multicolumn{2}{|c|}{1 ポンド当たり輸出金額 } \\
\hline 1955 & $\begin{array}{c}\text { エーカー } \\
566,394\end{array}$ & $\begin{array}{l}\text { 万ポンド } \\
380,013\end{array}$ & $\begin{array}{c}\text { ポンド } \\
671\end{array}$ & $\begin{array}{c}\text { 千辇ソド } \\
362,235\end{array}$ & $1,194,227$ & $\begin{array}{l}\text { ルピー } \\
3.29\end{array}$ & $251.85^{\text {म }}$ \\
\hline 1956 & 570,255 & 375,578 & 659 & 348,129 & $1,043,847$ & 2.99 & 228.88 \\
\hline 1957 & 570,573 & 397,775 & 697 & 366.750 & $1,015,896$ & 2.77 & 212.04 \\
\hline 1958 & 572,706 & 413,155 & 721 & 410,774 & $1,130,969$ & 2.75 & 210.51 \\
\hline 1959 & 579,652 & 413,130 & 713 & 383,495 & $1,045,013$ & 2.72 & 208.22 \\
\hline 1960 & 581,821 & 434,109 & 746 & 409,783 & $1,075,609$ & 2.62 & 200.56 \\
\hline 1961 & 587,401 & 455,229 & 775 & 425,721 & $1,113,967$ & 2.61 & 199.80 \\
\hline 1962 & 591,118 & 467,050 & 790 & 451,633 & $1,147,724$ & 2.54 & 194.44 \\
\hline
\end{tabular}

表 6 茶1 ポンド当たりの生産費（セント）

一。般 費

37.34 .

有給(日曜)貨金

14.09

建物などの維持費

3.26

医療・学校・食費の補助

4.76

地代・税金・保険

3.49

10.84

そ の他

その他の雑費

0.90

ほ場維持管理費

儥金その他( 除草, 摘

採, 病虫害(駆除, 肥料)

86.60

64.48

賃金（移植，せ九枝，その他） 7.82

材 料 13.45

その他の雑費 · 0.85

主場製造費

25.41

貨金

8.31

機械、維持 費

2.22

燃料費その他

14.88

149.35

(114円34銭) blight, virus.

幹 : collar canker, branch canker.

根 : red root disease, black root disease, brown root disease, charcoal root disease. primary root disease, root splitting disease, armullaria root disease

(6) 害虫

おむな害虫は次のものである。

shot hole borer, tea tortrix, scarlet mite, yellow mite, red spider mite, purple mite, white grubs; scale insect, thrips, 線虫として, meadow nematodes 最も多人, pin nematodes, Meloidogyne brevicauda, Helicotylenchus dihystera, Scutellonema brachyurum, Pratylenchus Loosii が存在する。

摘採はほとんど年中行なわれ，低地は 5 日間隔に，高

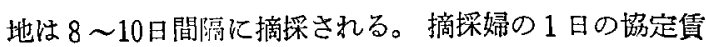
金は1.98ルピー（約 142 円）で，責任摘採量は25ポンド で，1ポンド超過に対し0.07ルピー支給される。低地ほ ど摘探回数が多く，収量は多いが，茶の品質は逆に高地 ほど良い。また，雨期汉収量は多いが品質注悪く，逆に 乾期治収量は少ないが品質は良い。セイロンは南西モン 
スーン期, 北西モンスーン期, 中間期の 3 季に分かれる ので，一地方に雨が降る時，他地方はかわき，したがっ て1年中どこかが晴れて良い紅茶ができる。

茶園面積, 生産量, 輸出量を表 5 亿示す。茶園面積, 生産量, 輸出量ともに増加してきている。しかし, 本年 度の生産量は前年度の生産量 46900 万ポンドより少なく なっているとのことである。これは肥料の供給が十分で
なく、不足したことと，低地産の茶を安く買うため、こ の地方では製産費を安くするように管理を省いたことな どがあげられている。

生産費についての結果を表 6 亿示す。これは145 エス テートの $1959 ， 1960$ 年の 2 年平均值である。1 ポンド 当たり約 114 円で 1959，1960年の生産量からみると， 1 エーカー当たりの平均生産費は 83,400 円程度となる。 表（1959 1963）

\begin{tabular}{|c|c|c|c|c|c|c|c|c|c|}
\hline \multirow{2}{*}{ 月 } & 低 & \multicolumn{2}{|c|}{ 地 (Ratnapura) } & \multicolumn{2}{|l|}{ 中 } & 地 (Kandy) & \multicolumn{3}{|c|}{ 高 地 (Nuwara Eliya) } \\
\hline & 平均気温 & 湿 & 降雨量 & 平均気温 & 湿 & 降雨量 & 平均気温 & 湿 & 降 雨 量 \\
\hline 1 & $26.9^{\circ} \mathrm{C}$ & $72^{\%}$ & $\frac{\mathrm{mm}}{159.2^{-}}$ & $23.1^{\circ} \mathrm{C}$ & $70^{\%}$ & $\underbrace{}_{161.0^{\mathrm{mm}}}$ & $14.2^{\circ} \mathrm{C}$ & $71^{.86}$ & $\frac{\mathrm{mm}}{176.7^{-1}}$ \\
\hline 2 & 27.4 & 65 & 134.6 & 23.8 & 60 & 58.6 & 14.2 & 60 & 40.5 \\
\hline 3 & 28.0 & 70 & 206.3 & 25.2 & 62 & 148.3 & 14.8 & 62 & 103.8 \\
\hline 4 & 28.1 & 74 & 293.1 & 26.0 & 69 & 174.8 & 16.0 & 69 & 126.4 \\
\hline 5 & 27.7 & 76 & 531.3 & 25.8 & 71 & 192.2 & 16.6 & 77 & 215.1 \\
\hline $6^{\prime}$ & 27.0 & 78 & 461.1 & 24.6 & 76 & 224.2 & 16.1 & 84 & 265.4 \\
\hline 7 & 27.0 & 76 & 324.3 & 24.2 & 76 & 185.9 & 15.6 & 84 & 279.4 \\
\hline 8 & 26.9 & 74 & 289.3 & 24.6 & 74 & 145.5 & 15.7 & 82 & 190.9 \\
\hline 9 & 28.8 & 74 & 368.8 & 23.8 & 72 & 163.5 & 15.6 & 81 & 209.2 \\
\hline 10 & 26.6 & 77 & 457.2 & 24.7 & 74 & 267.7 & 15.5 & 80 & 247.8 \\
\hline 11 & 26.6 & 78 & 375.6 & 24.3 & 75 & 279.4 & 15.3 & 79 & 234.4 \\
\hline 12 & 26.6 & 76 & 231.6 & 23.3 & 73 & 214.3 & 14.7 & 76 & 198.3 \\
\hline $\begin{array}{c}\text { 計 } \\
\text { 平 均 }\end{array}$ & 27.3 & 74.1 & 3832.4 & 24.4 & 71.0 & 2215.4 & 15.4 & 75.4 & 2287.4 \\
\hline
\end{tabular}

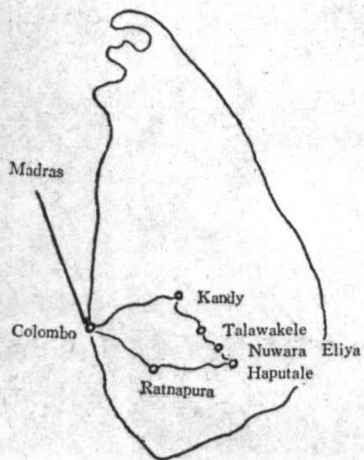

図２セイロンにおける訪問先

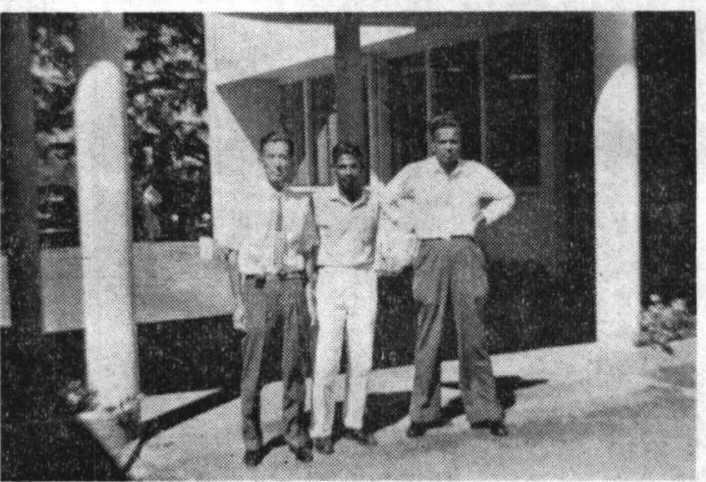

写真 6 St. Coombs の茶業試験場 中央 SEBARTIAMPILLAI 氏（育種担当）

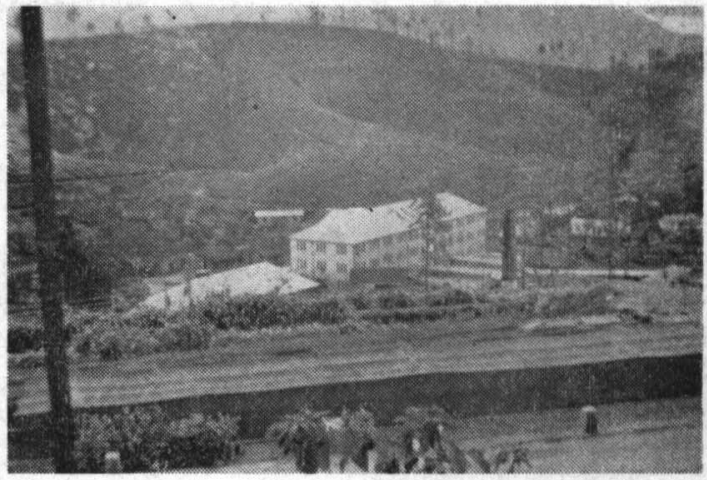

写真 7 St. Coombs の茶業試験場

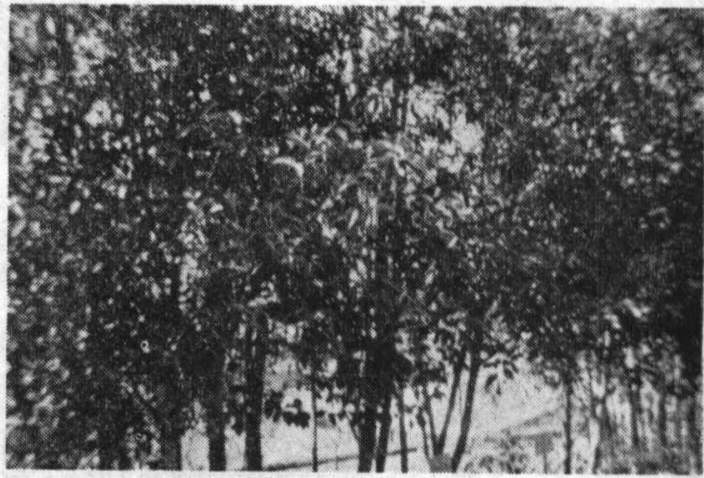

写真 8 TRI-2024. TRI-2025 原木

(St. Coombs の茶業試験場) 


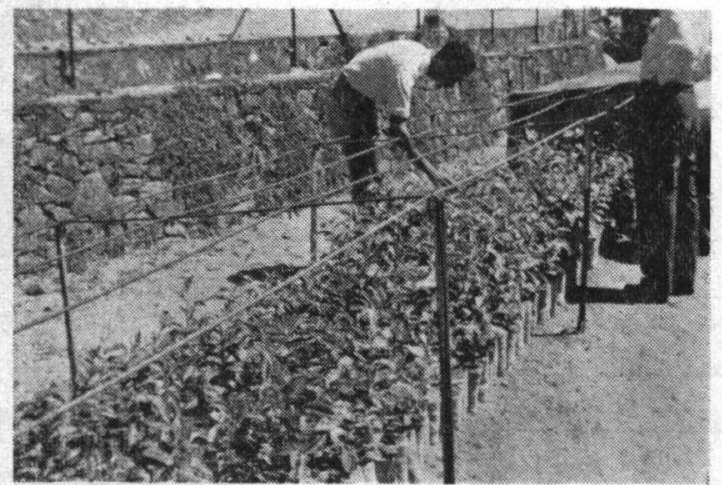

写真 9 さし木苗床 (St. Coombs の茶業試験場)

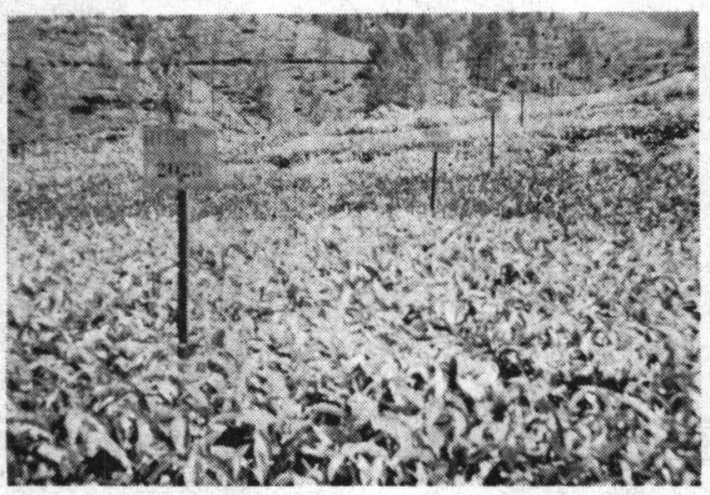

写真10 品種比較試験 (St. Coombs の茶業試験場)

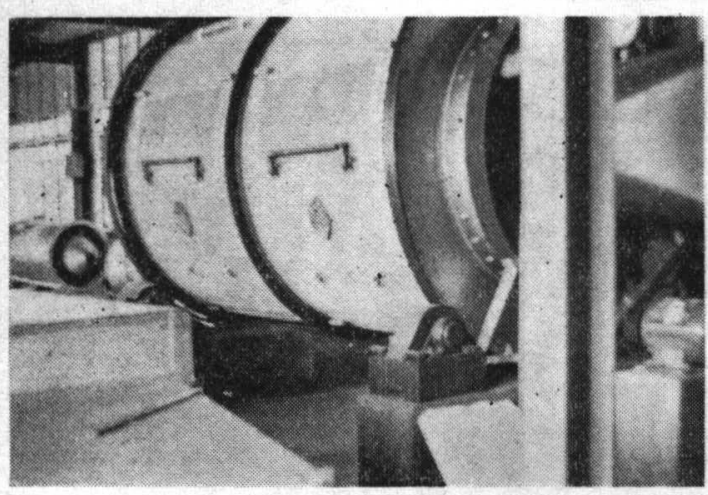

写真11 人工萎调機 (St. Coombs の茶業試験場)

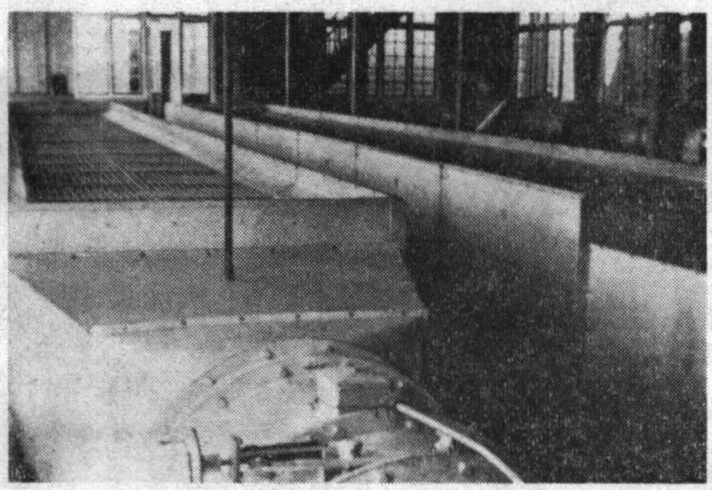

写真12人工萎调機 (St. Coombs の茶業試験場)

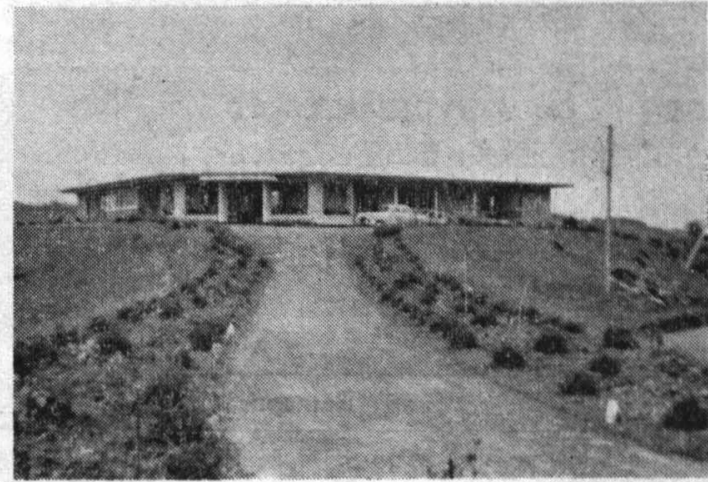

写真13 Ratnapura の低地試験地

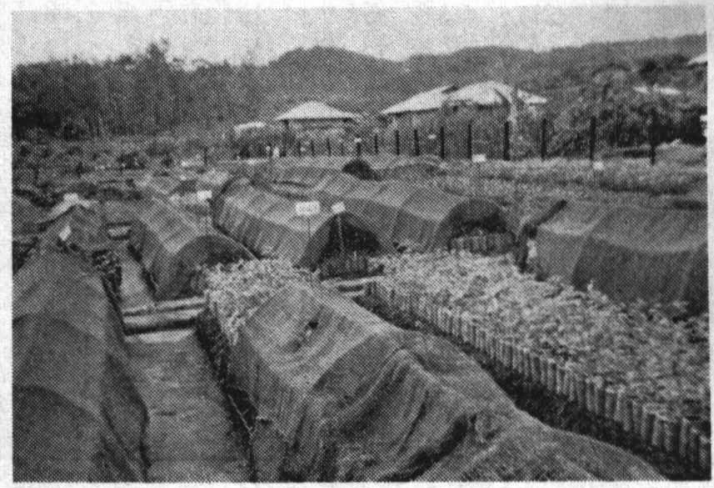

写真14さし木苗床 (Ratnapura の低地試験地)

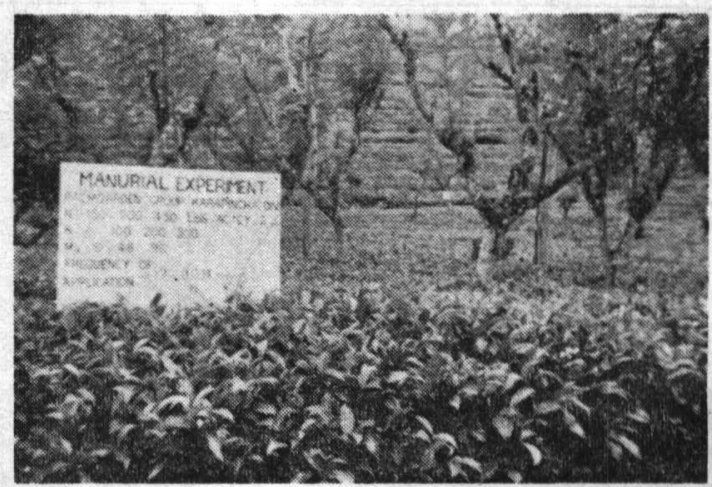

写真15 施肥法試験 (Ratnapura の低地試験地)

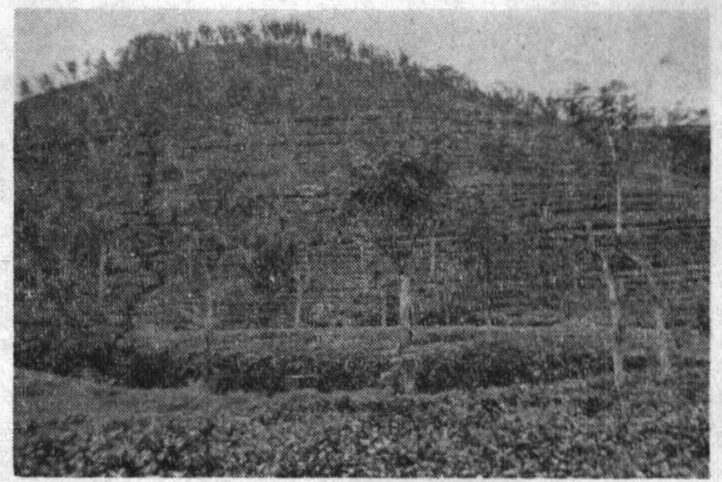

写真16 Talawakele の茶園 


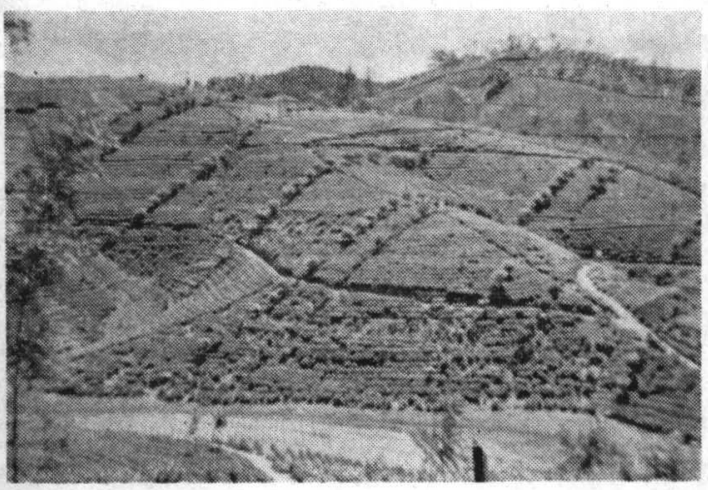

写真17 Nuwara Eliya の茶園

\section{5 東パキスタン}

12月 6 日に Colombo を出発し, 途中 Calcutta に1 泊して, 12月7日に Dacca に到着してから12月13日ま で滞在した。その間に Sylhet を訪間し，Tea Research Station, 主要エステートにおいて茶業事情の調査を行な った。

日本総領事館竹中総領事, 浅井領事, Agricultural Extention Training Institute の山口, 岩岡, 山下, 守 屋, 原田, 小林各技師の御指導をいただき, Sylhet の茶 業調査には山下技師および助手の A.M. MUTIN 氏の同 行を得て, 多大の協力, 配慮をいただいた。なお, 森理 事長出張のため面接できなかったことは誠に残念であっ た。

試験場の訪問に多くの時間を費したこともあり，試験 場と 2 エステートおよび各地の茶園を見学したのみで， 十分な調査はできなかった。

\section{1 調 查の概 要}

栽培種 : 茶栽培地帯は標高 20 〜 $0 \mathrm{~m}$ の間にあり, しか

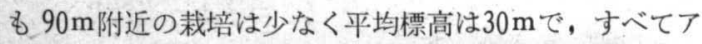
ッサム雑種が栽培されている。

品種の育成 : 現在繁殖には種子が多く利用され, 種子 用の苗床も多い。まだ育種事業は大規模に行なわれてい ない。育種方法は自然種子利用による分離育種法で, 試 験場, Ptras Farm, Nurjahan Tea Estate で育種が行 なわれている。現在まで育成された品種は19/29/13 (TV 1), 20/23/1 (TV 2), B 18/38, B 138/39, В 200/39, B $201 / 39$, B 207/39, B 225/35, B 223/39 などがあ り，その他選抜された66の優良采統がある。

交雑育種法はごく小規模に取り入れ始めたに過ぎず， 支那種とアッサム雑種の組合せである。

繁殖：試験場においては, 種子繁殖法, さし木繁殖法 を検討している。種子繁殖法については, 混合採種した 種子のなかから大きい種子を選び，これを催芽し，苗床 には種し、できるだけ樹勢, 葉の大きさ, 葉色などにつ いて均整度它高める方法, 苗床における生育促進法（生
育促進剂，施肥法）について検討している。なお，茶樹 の開花の最盛期は11 12月で, 採種時期は11月である。 さし木繁殖法については, さし穂の予措, 生育促進法, 移植の方法について検討されている。さし木は主要エス テートでも行なっている。さし穂は台刚り後に発生する 徒長枝のみを用い, 一葉ざし, ポリエチレン袋の利用な どはインド，セイロンと同じである。床土は表土（砂土 に富さ）をそのまま利用し，苗床は一般に大きい。日お おいの材料は，竹の産地であるがためすべて竹製のも で, 苗床の内部の照度は低く暗い。さし木の時期は11月 で,さし木の活着は良く80\%に達している。

現在増殖計画の途上にあり, 表 8 で示すようにエステ 一トで採種された種子を主体として, 一部さし木苗が植 えつけられている。

表 8 種子の生産量 (マンド)

\begin{tabular}{l|r|r|r}
\hline 年 度 & 生産 量 & 要 求 量 & 過不足分 \\
\hline $1959 \sim 1960$ & 1,851 & 2,459 & -608 \\
$1960 \sim 1961$ & 921 & 2,225 & $-1,308$ \\
$1961 \sim 1962$ & 2,942 & 2,654 & +269 \\
$1962 \sim 1963$ & 2,002 & 2,646 & -644 \\
\hline
\end{tabular}

定植後の管理 : 実生苗およびさし木苗は, は種および さし木後 1 年 4 カ月の 4 月ごろに定植される。定植時の 栽植様式は, $120 \times 60 \mathrm{~cm}$ (うね幅 $\times$ 株間), $120 \times 120 \mathrm{~cm}$, $135 \times 135 \mathrm{~cm}, 150 \times 75 \mathrm{~cm}$, 二条植えの $120 \times 60 \times 60 \mathrm{~cm}$, $150 \times 75 \times 75 \mathrm{~cm}$ な゙があるが, $120 \times 60 \mathrm{~cm}, 120 \times 60 \times 60$ $\mathrm{cm}, 150 \times 75 \times 75 \mathrm{~cm}$ の様式が良い。実生種もすべて直 立型であるが, 苗床時のせん枝, 定植後に主幹をまげて 側枝の発生を促すようなことはしないが，定植後のしゃ 光は考虑し, 間作物について検討し,また,一部では丸 い竹編みのものを株ごとにおいたりしている。幼木の仕 立あるいは中刚り後の仕立法はインド, セイロンと大差 はない。中刈りは 45 60 cm にし, その周期は $4 \sim 5$ 年 である。肥料は収量に応じて施し, 製茶量 10 ポンドに 対し, 窒素 1 ポンドの割合で年 $2 \sim 3$ 回に分施する。一 般にリン酸, カリの効果は少ないとして 窒素質肥料のみ 施している。窒素質肥料でも尿素（効果が劣る) は使わ ずに硫安のみ使用しているが, 硫安の連続施用の悪影響 はみられない。被陰樹は必ず植え, albizzia, acacia が多 い。病害のおもなものは blister blight, red rust disease, branch canker で害虫のおもなものは red spider mite, flush worm, bag worm, looper caterpillar, green caterpillar, nematodes などである。

\section{2 試験場におけるおむな研究項目}

(a) 品種改良に関する研究 
1. 新品種育成に関する研究

2. 種子の能力試験

(b) 栽培に関する研究

1. さし穂の予措に関する研究

2. 翼床に和汀る実生個体の生育促進に関する研究

3.さし木苗, 実生苗の移植法汇関する研究

4. 気象条件之茶の収量との関综

5. せん枝時期が樹勢, 収量, 品質に及ぽす影響

6。栽植密度が生育，収量に及ぼす影響

7. 季節風前のかんがいが収量に及ぼす影響

8. 除草剂利用試験

9. 落葉防止試験

(c) 土㙵肥料に関する研究

1. 土㙴調査

2. 管理状況の実態調查

3. 苗床の実生苗に対する三要素施用試験

4. 幼木に対方る施肥法試験

5. 成木に対拉る三要素試験

6. 尿素々硫安との比較試験

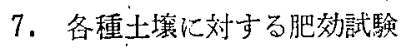

8. 不灰の肥効試験

9. 微量要素施用試験

(d) 病害虫に関する研究

1. red rust disease, blister blight 駆除試験

2. 各種害虫の (red spider mite, bag worm, flush worm, looper caterpillars, nematodes) 防除陚駿

(e) そ $の$ 他

1. 茶の種類別花粉の発芽力の比較試験

2. 茶樹の内部組織汇関する研究

3. 時期別茶菜の窒素成分の変化

4. 各種窒素質肥料が茶葉成分に及ほす影響

5. 窒素、リン酸の施用が茶菜成分に及ぼす影響

月別の生産量を表 9 に示すが， 1 ～ 3 月の收量 はるず かであり，12月摘採の生荣の品質は他の月に比較して悪 い。生産量の多い月は6〜11月の6力月間であるが，と のうち6〜8月は降雨量多く，品質法劣る。また，標高 は 20 90m の間で，標高差による品質の違いは全くな く，概してごく良質の茶は得られていない。

表 9 月別生産量（万ポンド）

\begin{tabular}{c|c|c|c|c|c|c|c|c|c|c|c|c}
\hline 年度 & 1月 & 2月 & 3月 & 4月 & 5月 & 6月 & 7月 & 8月 & 9月 & 10月 & 11月 & 12月 \\
\hline 1955 & - & - & - & 2.66 & 2.91 & 5.51 & 6.74 & 7.83 & 7.70 & 7.71 & 7.83 & 3.62 \\
1956 & - & - & - & 3.09 & 4.26 & 5.71 & 7.43 & 8.41 & 8.32 & 8.22 & 6.44 & 3.31 \\
1957 & 0.32 & 0.10 & 0.59 & 1.08 & 3.09 & 4.21 & 7.04 & 6.69 & 8.84 & 8.01 & 5.11 & 2.54 \\
1958 & 0.41 & 0.09 & 0.51 & 2.35 & 4.23 & 5.39 & 8.20 & 8.94 & 8.40 & 8.38 & 6.68 & 3.95 \\
1959 & 0.35 & 0.16 & 0.55 & 3.05 & 4.57 & 5.69 & 8.35 & 8.62 & 8.94 & 7.60 & 6.15 & 3.35 \\
1960 & 0.30 & 0.04 & 0.44 & 0.84 & 0.75 & 4.43 & 4.18 & 6.91 & 7.11 & 7.80 & 5.72 & 3.09 \\
1961 & 0.42 & 0.08 & 0.72 & 3.01 & 3.97 & 6.18 & 8.20 & 9.47 & 9.05 & 8.59 & 6.63 & 2.72 \\
\hline 平均 & 0.36 & 0.09 & 0.56 & 2.30 & 3.40 & 5.30 & 7.17 & 8.12 & 8.34 & 8.04 & 6.39 & 3.23 \\
\hline
\end{tabular}

表 10 茶園面積・生産量・翰出量

\begin{tabular}{|c|c|c|c|c|}
\hline 年 & 茶園面積 & 茶生産量 & $\begin{array}{l}1 \text { 조 } \\
\text { 生当市量 }\end{array}$ & 輸出量 \\
\hline $1954 \sim 1955$ & $\begin{array}{l}\text { Fエーカ } \\
73.60\end{array}$ & $\begin{array}{c}\text { 万人ポソ } \\
54.63\end{array}$ & $\begin{array}{l}\text { ポソ } \\
742\end{array}$ & $\begin{array}{l}\text { 万ポソ } \\
26.15\end{array}$ \\
\hline $1955 \sim 1956$ & 73.96 & 52.51 & 710 & 12.27 \\
\hline $1956 \sim 1957$ & 74.89 & 56.20 & 750 & 24.76 \\
\hline $1957 \sim 1958$ & 75.45 & 47.61 & 631 & 7.25 \\
\hline $1958 \sim 1959$ & 76.50 & 57.59 & 752 & 11.74 \\
\hline $1959 \sim 1960$ & 77.31 & 57.11 & 739 & 17.67 \\
\hline $1960 \sim 1961$ & 78.16 & 42.24 & 540 & 0.49 \\
\hline $1961 \sim 1962$ & 78.89 & 58.46 & 741 & 12.09 \\
\hline $1962 \sim 1963$ & 80.70 & 51.83 & 642 & 4.19 \\
\hline $1963 \sim 1964$ & 83.70 & 55.53 & 663 & 0 \\
\hline
\end{tabular}

最近国内需要が增し，輸出を禁止し，増殖实施中であ る(表10)。

Sylhet 地区の生産費を取りまとめだ資料がなかったの で、あるェステートで調べた結果を表11に示す。このエ
表 11 生産費（1エーカー当たり）

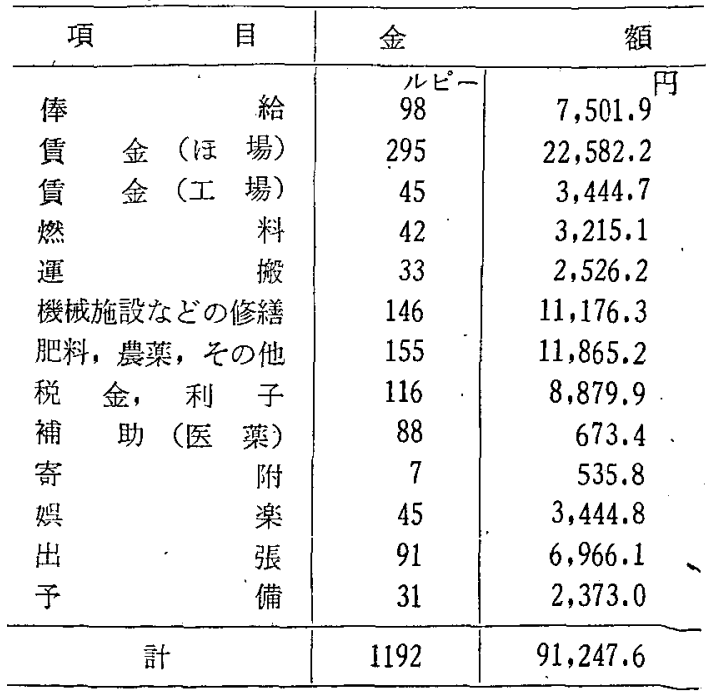


表 12 気像表 (Pakistan Tea Research Station)

\begin{tabular}{|c|c|c|c|c|c|}
\hline \multirow{2}{*}{ 月 } & \multirow{2}{*}{ 降雨量 } & \multirow{2}{*}{ 降雨日数 } & 気 & 温 & \multirow{2}{*}{ 湿 度 } \\
\hline & & & 最 高 & 最 低 & \\
\hline 1 & $\frac{\mathrm{m} \mathrm{m}}{15.2}$ & $1^{\text {日 }}$ & $25.6^{\circ} \mathrm{C}$ & $8.6^{\circ} \mathrm{C}$ & 87 \\
\hline 2 & 42.4 & 4 & 31.6 & 14.1 & 84 \\
\hline 3 & 2.0 & 1 & 33.2 & 18.4 & 75 \\
\hline 4 & 116.3 & 11 & 32.6 & 26.1 & 70 \\
\hline 5 & 232.4 & 13 & 33.5 & 23.1 & 86 \\
\hline 6 & 726.4 & 22 & 32.4 & 25.5 & 86 \\
\hline 7 & 374.6 & 15 & 32.5 & 27.1 & 87. \\
\hline 8 & 323.8 & 20 & 32.9 & 25.4 & 84 \\
\hline 9 & 69.1 & 5 & 32.2 & 25.8 & 88 \\
\hline 10 & 64.2 & 4 & 31.1 & 25.7 & 90 \\
\hline 11 & - & - & 27.1 & 16.7 & 88 \\
\hline 12 & - & - & 25.1 & 8.57 & 78 \\
\hline
\end{tabular}

ステートは 2,000 エーカーの 茶園を有する代表的なもの であり，1 エーカー当たりの平均茶生産量は 1,300 ポン ド, 茶の 1 ポンド当たりの平均価格は 1.3 ルピー（約 100 円）である。これからみると，このエステートの 1 エー カー当たりの平均粗収入は129,350円となる。

Khadim Tea Estate は丸山式摘採機を導入している が, 他の摘採機の照会を, また Tea Research Station がらは摘採機およびタ゚スターの照会を依頼された。

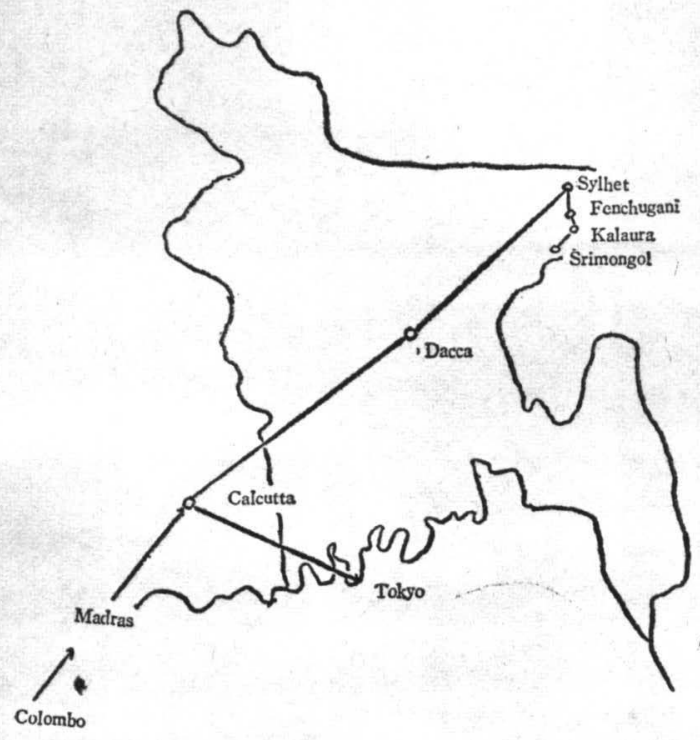

図３＼cjkstart東パキスタンにおける訪問先

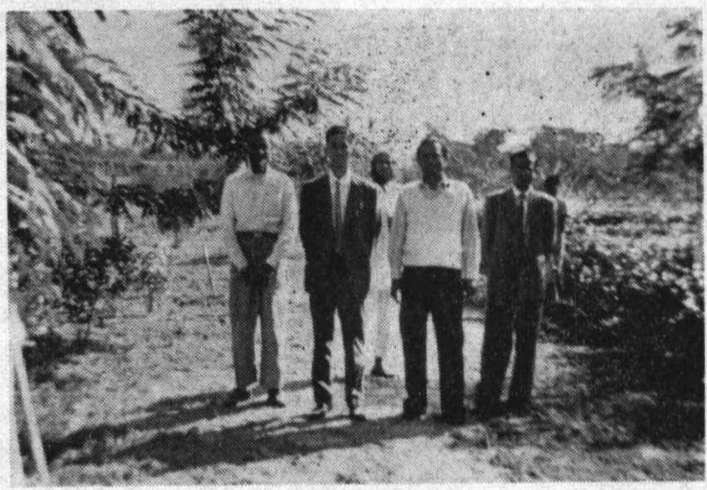

写真18 Pakistan 茶業試験場長（右から二人目）

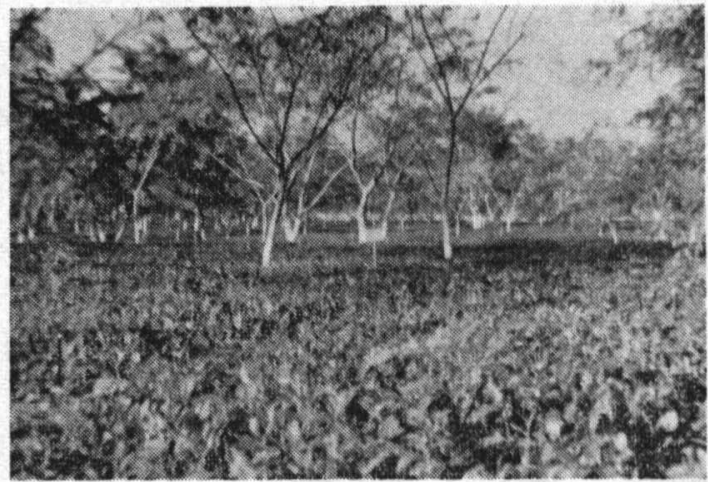

写真19 Pakistan 茶業試験場ほ場

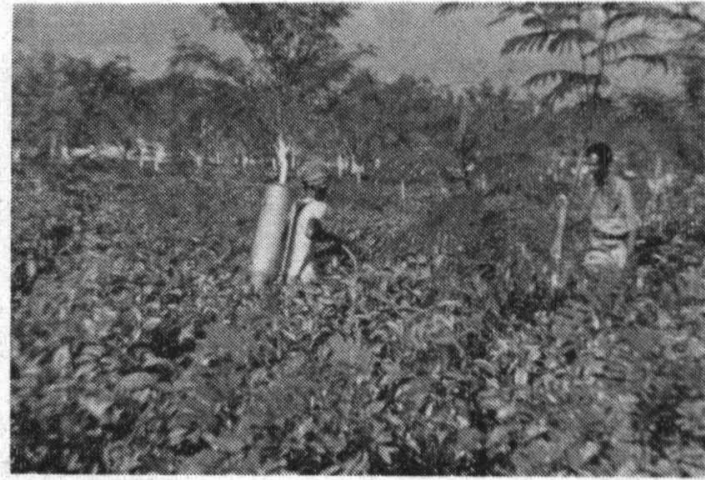

写真20 Pakistan 茶業試験場ほ場

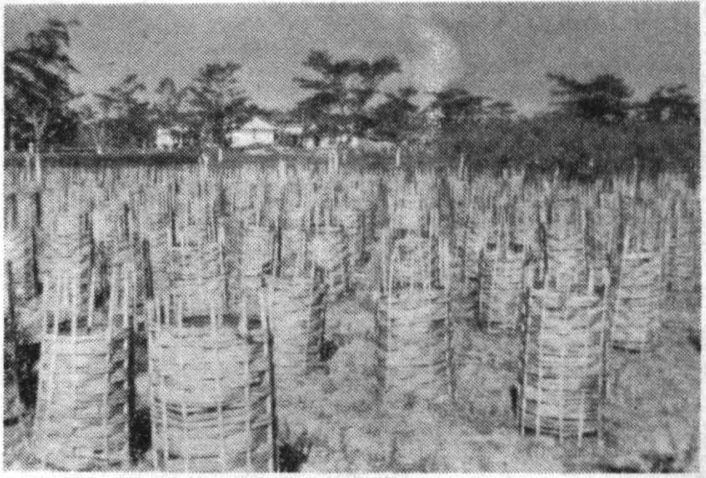

写真21 定植後の幼木の管理（Pakistan 茶業試験場） 


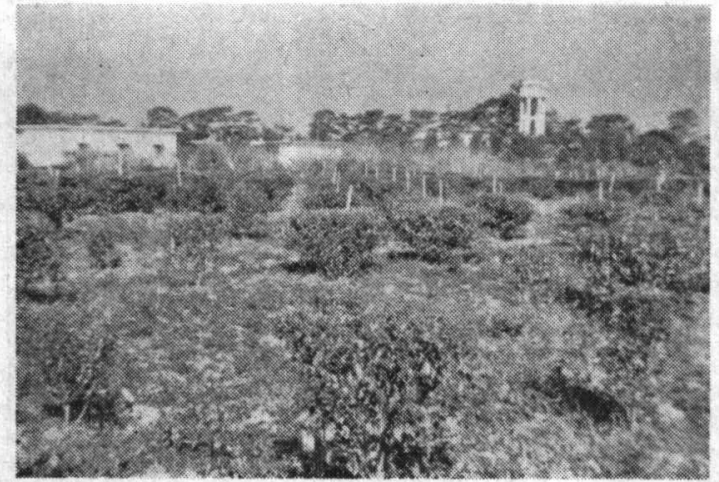

写真22 個体選抜ほ場 (Pakistan 茶業試験場)

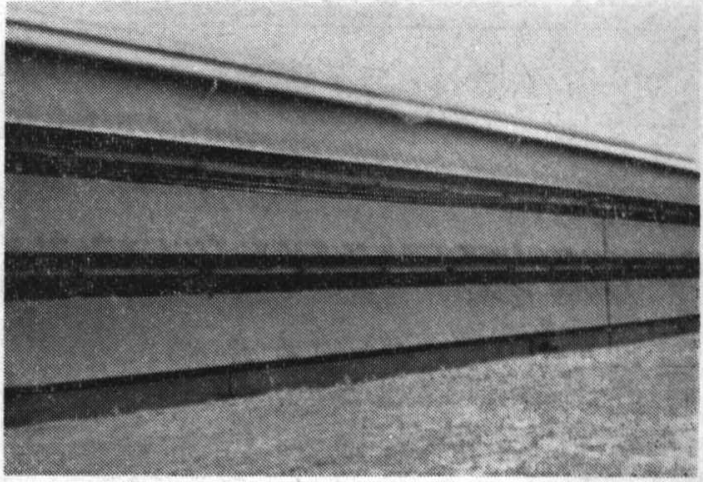

写真23 萎调用建物 (Larkatoorah Estate) 